\title{
Notes on reproduction of Peters' Leaf-toed Gecko, Phyllodactylus reissii (Squamata, Gekkonidae), from Peru
}

\author{
Stephen R. Goldberg \\ Department of Biology, Whittier College, Whittier, California 90608, USA. E-mail: sgoldberg@whittier.edu.
}

Keywords: Squamata, Gekkonidae, Phyllodactylus reissii, reproduction, Peru.

Species of Phyllodactylus occur in semiarid to arid regions along the Pacific coast in extreme southern California, Baja California and western Mexico through Central America, some of the Caribbean Islands, northern Colombia, southern Venezuela, the Galapagos Islands, northwestern Peru and northern Chile (Dixon 1973, Savage 2002). Peter's Leaf-toed Gecko, Phyllodactylus reissii (Gekkonidae) is known from southern Ecuador and northwestern Peru from sea level to ca. 2000 m (Dixon and Huey 1970). Its primary habitat appears to be arid tropical scrub west of the Andes and cacti dominated areas of the northern interandian basins of Peru (Dixon and Huey 1970). To my knowledge, the only information on its reproductive biology is a report of egg clutches in Dixon and Huey (1970). The purpose of this note is to add information on the reproductive biology of $P$. reissii from a histological examination of gonadal material from museum specimens. The first information on the testicular cycle is presented. Information on reproduction of $P$. reissii is compared with that

Received 3 October 2007.

Accepted 26 November 2007.

Distributed December 2007. of other species of Phyllodactylus from Mexico and South America.

Ninety-one $P$. reissii from Peru were examined from the herpetology collection of the Natural History Museum of Los Angeles County (LACM), Los Angeles, California, USA. The sample consisted of 50 females (mean SVL = $54.4 \mathrm{~mm} \pm 6.6 \mathrm{SD}$, range: $40-67 \mathrm{~mm}), 35$ males (mean SVL $=56.7 \mathrm{~mm} \pm 4.7 \mathrm{SD}$, range: 48-67 $\mathrm{mm}$ ) and 6 neonates (mean SVL $=26.8 \mathrm{~mm} \pm$ $2.3 \mathrm{SD}$, range: $23-30 \mathrm{~mm}$ ). Lizards were collected 1968 and 1976. Museum catalogue numbers of examined specimens are given in the Appendix I by Peruvian Department.

For histological examination, the left testis and epididymis were removed from males and the stages in the testicular cycle were identified. The left ovary was removed from females for histological examination to check for the presence of vitellogenesis (yolk deposition). Enlarged follicles ( $>4 \mathrm{~mm}$ diameter) or oviductal eggs were counted. Tissues were embedded in paraffin and cut into sections at 5 $\mu \mathrm{m}$. Slides were stained with Harris hematoxylin followed by eosin counterstain (Presnell and Schreibman 1997). An unpaired t-test was used to compare $P$. reissii male versus female mean body sizes (Instat vers. 3.0b, Graphpad Software, San Diego, CA). 
An unpaired $t$-test revealed there was no significant size difference between mean male and female body sizes (SVL). The only stage observed in the testicular cycle of $P$. reissii was spermiogenesis (= sperm formation) in which the borders of the seminiferous tubules are lined by rows of metamorphosing spermatids and spermatozoa are abundant. The histology of the seminiferous tubules undergoing spermiogenesis was similar to that observed by Goldberg (1974). All epididymides contained sperm. Phyllodactylus reissii males examined by month were November $(\mathrm{N}=20)$, December (10), May (4), June (1). The smallest reproductively active males measured $48 \mathrm{~mm} \mathrm{SVL}$ and were from November (LACM 48769) or December (LACM 48793, 48796).

Five stages were observed in the ovarian cycle (Table 1). Reproductively active females were found in November, December, and May. The presence of females from November and December with oviductal eggs and concomitant yolk deposition as well as females from May with corpora lutea from a previous clutch and concomitant yolk deposition for a subsequent clutch indicate $P$. reissii females produce multiple clutches in the same year. Ovarian histology was similar to that in Goldberg (1973, 1976). Mean clutch size for 27 P. reissii females was $1.70 \pm 0.47 \mathrm{SD}$, range: $1-2$. The smallest reproductively active female (in early yolk deposition) measured $40 \mathrm{~mm}$ SVL (LACM
48821) and was from December; another slightly larger female (in early yolk deposition) from the same month (LACM 48797) measured $43 \mathrm{~mm}$ SVL.

Six presumably neonates (SVL range: 23-30 $\mathrm{mm}$ ) were collected. Five were from November and one was from May.

Clutch sizes of Phyllodactylus from Peru are listed in Dixon and Huey (1970) and include one egg produced by Phyllodactylus angustidigitus, Phyllodactylus gerrhopygus, Phyllodactylus inaequalis, Phyllodactylus interandinus, Phyllodactylus kofordi, Phyllodactylus lepidopygus, Phyllodactylus microphyllus, and Phyllodactylus johnwrighti and two eggs produced by $P$. reissii. Gravid $P$. kofordi and small juveniles were found in July, August, November and December (Dixon and Huey 1970).

Ramírez-Sandoval et al. (2006) studied Phyllodactylus lanei at Jalisco, Mexico, where this species has an extended reproductive season; females produce multiple clutches. Testes of maximum sizes occurred in August to March, declined beginning in April and were at a minimum in July. Maximum egg production occurred during January to April.

In the Isthmus of Tehuantepec, Oaxaca, Mexico, some females of Phyllodactylus muralis and Phyllodactylus tuberculosus contained mature eggs in all seasons of the year (Dixon 1964). Neonates were collected January,

Table 1 - Monthly stages in ovarian cycle of 50 Phyllodactylus reissii from Peru. Values shown are the numbers of females exhibiting each of the five conditions. *Sample includes 1 female with oviductal eggs and concomitant yolk deposition. ${ }^{* *}$ Sample includes 4 females with oviductal eggs and concomitant yolk deposition.

\begin{tabular}{lcccccc}
\hline Month & N & $\begin{array}{c}\text { No yolk } \\
\text { deposition }\end{array}$ & $\begin{array}{c}\text { Early yolk } \\
\text { deposition }\end{array}$ & $\begin{array}{c}\text { Follicles }>4 \mathrm{~mm} \\
\text { length }\end{array}$ & $\begin{array}{c}\text { Oviductal } \\
\text { eggs }\end{array}$ & $\begin{array}{c}\text { Corpora lutea and } \\
\text { yolk deposition }\end{array}$ \\
\hline November & 19 & 3 & 4 & 4 & $8^{*}$ & 0 \\
December & 17 & 1 & 6 & 3 & $7^{* *}$ & 0 \\
May & 12 & 5 & 0 & 1 & 4 & 2 \\
June & 2 & 2 & 0 & 0 & 0 & 0
\end{tabular}


February, April, June, August and December suggesting some reproduction occurs throughout the year (Dixon 1964). Thus, the above three Phyllodactylus species from Mexico and $P$. kofordi from Peru (Dixon and Huey 1970) exhibit extended periods of reproduction. The presence of presumably neonates of $P$. reissii in my samples from November and May also suggests an extended reproductive cycle.

In contrast, Goldberg (1997) reported that Phyllodactylus xanti from southern California exhibited a "typical temperate" reproductive cycle in which spermiogenesis occurred in spring, regression in summer and recrudescence (= recovery) took place in autumn. Females with oviductal eggs were found in May. This timing has been reported in the reproductive cycles of other lizards from various lizard families in California including the anguid Gerrhonotus multicarinatus (Goldberg 1972), phrynosomatids Sceloporus occidentalis (Goldberg 1974), Sceloporus vandenburgianus (Goldberg 1975), Uta stansburiana (Goldberg 1977), Phrynosoma coronatum (Goldberg 1983), scincid Eumeces skiltonianus (Goldberg 2005), teiid Aspidoscelis tigris (Goldberg 1976), and xantusiid Xantusia riversiana (Goldberg and Bezy 1974). This timing of events in the yearly reproductive cycle allows mating during spring, egg laying (except for viviparous $X$. riversiana) and appearance of young in mid-to-late summer when food is abundant. The above strategy allows growth and fat deposition so young may enter hibernation with sufficient reserves to survive the winter.

Because my samples do not include all months, I cannot characterize the complete reproductive cycle of $P$. reissii, nevertheless, some observations can be made. It is apparent that more than one egg clutch can be produced in the same year and that females produce 1-2 eggs per clutch. My finding of reproductively active $P$. reissii in both summer and autumn suggests an extended reproductive period, perhaps, similar to that of $P$. muralis, $P$. tuberculosus and P. lanei from Mexico (Dixon
1964, Ramírez-Sandoval et al. 2006) and $P$. kofordi from Peru (Dixon and Huey 1970). Examination of additional monthly samples of $P$. reissii is needed before the timing of all events in the reproductive cycle can be ascertained.

\section{Acknowledgements}

I thank Christine Thacker (LACM) for permission to examine specimens. Jessica Carlson (Whittier College) assisted with histology.

\section{References}

Dixon, J. R. 1964. The systematics and distribution of lizards of the genus Phyllodactylus in North and Central America. New Mexico State University, Scientific Bulletin 64-1: 1-139.

Dixon, J. R. 1973. Phyllodactylus Gray Leaf-toed geckos. Catalogue of American Amphibians and Reptiles 141: $1-2$.

Dixon, J. R. and R. B. Huey. 1970. Systematics of the lizards of the gekkonid genus Phyllodactylus of mainland South America. Los Angeles County Museum, Contributions in Science 192: 1-78.

Goldberg, S. R. 1972. Reproduction in the southern alligator lizard Gerrhonotus multicarinatus. Herpetologica 28: 267-273.

Goldberg, S. R. 1973. Ovarian cycle of the western fence lizard, Sceloporus occidentalis. Herpetologica 29: 284-289.

Goldberg, S. R. 1974. Reproduction in mountain and lowland populations of the lizard Sceloporus occidentalis. Copeia 1974: 176-182.

Goldberg, S. R. 1975. Reproduction in the sagebrush lizard, Sceloporus graciosus. American Midland Naturalist 93: 177-187.

Goldberg, S. R. 1976. Reproduction in a mountain population of the coastal whiptail lizard, Cnemidophorus tigris multiscutatus. Copeia 1976: 260-266.

Goldberg, S. R. 1977. Reproduction in a mountain population of the side-blotched lizard, Uta stansburiana (Reptilia, Lacertilia, Iguanidae). Journal of Herpetology 11: 31-35.

Goldberg, S. R. 1983. Reproduction of the coast horned lizard, Phrynosoma coronatum, in southern California. Southwestern Naturalist 28: 478-479. 
Goldberg, S. R. 1997. Phyllodactylus xanti (Leaf-toed Gecko). Reproduction. Herpetological Review 28: 152-153.

Goldberg, S. R. 2005. Reproductive cycle of the western skink, Eumeces skiltonianus (Sauria, Scincidae), in southern California. Texas Journal of Science 57: 295301.

Goldberg, S.R. and R. L. Bezy. 1974. Reproduction in the island night lizard, Xantusia riversiana. Herpetologica 30: 350-360.
Presnell, J. K. and M. P. Schreibman. 1997. Humason's Animal Tissue Techniques, $5^{\text {th }}$ Ed. Baltimore. The Johns Hopkins University Press. 572 pp.

Ramírez-Sandoval, E., A. Ramírez-Bautista and L. J. Vitt. 2006. Reproduction in the lizard Phyllodactylus lanei (Squamata: Gekkonidae) from the Pacific Coast of Mexico. Copeia 2006: 1-9.

Savage, J. M. 2002. The Amphibians and Reptiles of Costa Rica. A Herpetofauna Between Two Continents, Between Two Seas. Chicago. University of Chicago Press. 934 pp.

\section{Appendix I - Material Examined}

Phyllodactylus reissii from Peru (listed by Department) examined from the herpetology collection of the Natural History Museum of Los Angeles County (LACM).

Amazonas 48741, 48746, 48749, 48750, 48753-48756, 48758, 48759, 48762-48764, 48766, 48769, 48771, 48786; Cajamarca
48723-48728, 48730-48732, 48734-48737; Lambayeque 48709-48713, 48715-48721, 48773, 48813, 48821, 48823-48829, 123080, 123082-123089, 123091-123097, 123100, 123102, 123117, 123120; Piura 48780, 48781, 48783, 48785, 48802-48805, 48807, 48809, 48810; Tumbes 48787, 48788, 48790-48793, 48796, 48797. 